\title{
Carcinoma Arising in Nasal Papillomatosis
}

National Cancer Institute

\section{Source}

National Cancer Institute. Carcinoma Arising in Nasal Papillomatosis. NCI Thesaurus. Code C27389.

A rare squamous cell carcinoma that either arises from or is associated with the presence of inverted papilloma in the nose. 